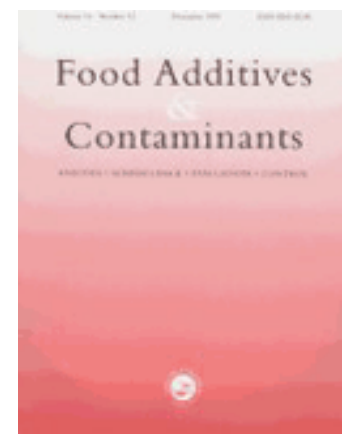

\title{
Development of a real time PCR protocol for the species origin confirmation of isolated animal particles detected by NIRM
}

\begin{tabular}{|c|c|}
\hline Journal: & Food Additives and Contaminants \\
\hline Manuscript ID: & TFAC-2010-063.R1 \\
\hline Manuscript Type: & Original Research Paper \\
\hline $\begin{array}{r}\text { Date Submitted by the } \\
\text { Author: }\end{array}$ & 26-Mar-2010 \\
\hline Complete List of Authors: & $\begin{array}{l}\text { Fumière, Olivier; Centre wallon de Recherches agronomiques, } \\
\text { Département Valorisation des Productions agricoles } \\
\text { Marien, Aline; Centre wallon de Recherches agronomiques, } \\
\text { Département Valorisation des Productions agricoles } \\
\text { Fernández Pierna, Juan; Centre wallon de Recherches } \\
\text { agronomiques, Département Valorisation des Productions agricoles } \\
\text { Baeten, Vincent; Centre wallon de Recherches agronomiques, } \\
\text { Département Valorisation des Productions agricoles } \\
\text { Berben, Gilbert; Centre wallon de Recherches agronomiques, } \\
\text { Département Valorisation des Productions agricoles }\end{array}$ \\
\hline Methods/Techniques: & Authenticity, Molecular biology - PCR \\
\hline Additives/Contaminants: & Animal products \\
\hline Food Types: & Animal feedingstuffs, Animal feed \\
\hline
\end{tabular}

\section{SCHOLARONE $^{\text {TM }}$ Manuscripts}


1 Development of a real-time PCR protocol for the species origin

2 confirmation of isolated animal particles detected by NIRM

3

4 Olivier Fumière*, Aline Marien, Juan Antonio Fernández Pierna, Vincent

5 Baeten and Gilbert Berben

6

8 Centre wallon de Recherches agronomiques (CRA-W).

9 Département Valorisation des Productions agricoles.

10 Bâtiment Henseval, Chaussée de Namur, 24. B-5030 Gembloux (Belgique)

11 The first two authors contributed equally to this work

12

20 Corresponding authors:

21 Olivier Fumière

22 E-mail: fumiere@cra.wallonie.be 
23 Abstract

24 At present, European legislation prohibits totally the use of processed animal 25 proteins (PAPs) in feed for all farmed animals [Commission Regulation (EC) $26 n^{\circ} 1234 / 2003$ - extended feed ban]. A softening of the feed ban for non-ruminants

27 would nevertheless be considered if alternative methods could be used to gain more

28 information concerning the species origin of PAPs than that which can be provided by 29 classical optical microscopy. This would allow control provisions such as the ban of 30 feeding animals with proteins from the same species or intra-species recycling

31 [Regulation (EC) $\left.n^{\circ} 1774 / 2002\right]$. Two promising alternative methods, Near Infrared

32 Microscopy (NIRM) and real-time Polymerase Chain Reaction (PCR) were combined

33 to authenticate, at the species level, the presence of animal particles. The present

34 paper describes the improvements of the real-time PCR method which were made to

35 the DNA extraction protocol, allowing 5 PCR analyses to be performed with the DNA

36 extracted from a single particle.

Keywords: PAP, animal proteins, BSE, feed ban, real-time PCR, NIRM. 


\section{Introduction}

Since the outbreak of bovine spongiform encephalopathy (BSE), the use of processed animal proteins (PAPs) including meat and bone meal as feed ingredients for farmed animals is drastically controlled within the European Union through several regulations (Regulation (EC) 999/2001, Regulation (EC) 1774/2002 and Regulation (EC) 1234/2003). Presently, classical optical microscopy is the only official method for the detection of PAPs in compound feed in the European Union [Commission Regulation (EC) $152 / 2009$ ] but the method offers very limited species discrimination perspectives. The Regulation (EC) 152/2009, however, stated that alternative methods can be used to gain more information about the origin of the PAPs. The capabilities of the different analytical methods for the detection, the species identification and the quantification of PAPs in feedingstuffs were recently reviewed by Fumière et al. (2009). Among the developed alternative methods, NIRM (Near Infrared Microscopy) and PCR (Polymerase Chain reaction) are in-house validated and routinely used under accreditation (ISO 17025 standard) at the Walloon Agricultural Research Centre. Moreover, they have been successfully assessed in international inter-laboratory studies describing their performance profile and their specific pros and cons (e.g. Prado et al., 2007). Other validation studies were conducted under the framework of the European SAFEED-PAP project. The results of these studies will be published soon.

Since 1998, the NIRM method that combines a NIR spectrometer and a microscope is in development at CRA-W for the detection of animal by-products in feed (Piraux and Dardenne 2000). Through different Belgian and European projects e.g. STRATFEED and SAFEED-PAP, the method was continuously improved and the discrimination between terrestrial PAPs and fish by-products on particles from the whole sample (raw fraction) and the particles having a density $>1.62$ obtained through a sedimentation process with tetrachloroethylene (sediment fraction) has been demonstrated (Baeten et al. 2004; Baeten et al. 2005; De la Haba et al. 2007; von Holst et al. 2008). 
Looking at the discrimination between PAPs particles from terrestrial animal species, the results obtained in previous studies tend to indicate that it might be possible. Nevertheless, such information is only considered as an indication and could not be used as a forensic result. An interesting aspect of the NIRM is the non-destructive property of the method towards the analysed samples thereby allowing to isolate the suspicious particles and to perform additional analyses.

PCR is currently the only technique able to determine the origin of animal by-products present in a feed at the species level. Thanks to the good stability of the DNA to high temperatures and rendering processes, different real-time PCR methods using small sized multi-copy targets already proved their efficiency for the detection of PAPs in animal feed at low level (Aarts et al. 2006; Fumière et al. 2006; Prado et al. 2007; Cawthraw et al. 2009). Nevertheless, PCR alone is not sufficient to evidence non compliance with the feed ban as it cannot distinguish authorised animal DNA sources (e.g. blood or milk products) from forbidden ones. Due to the high sensitivity of some PCR methods, the species origin of by-products containing only traces of DNA such as fat (e.g. tallow) can be determined (Bellorini et al. 2005) and could even lead to false positive results from a legal point of view (Prado et al. 2007).

The combination of both techniques allowing the detection of individual PAPs particles by NIRM and their authentication at a species level by real-time PCR was therefore investigated. This paper describes the last developments achieved in the PCR protocol to determine the origin of a PAPs particle at a species level with 5 PCR.

\section{Materials and methods}

Samples. The raw materials used in this study are all representative of the real world feed ingredients: the meat and bone meals were obtained from plants members of the European Fat Processors and Renderers Association (EFPRA ) and were produced as required by European 
legislation (heat treatment at a temperature of $\geq 133{ }^{\circ} \mathrm{C}$ and 3 bars for $20 \mathrm{~min}$ ). Concerning the authorised ingredients, the blood powders were also provided by the EFPRA. The egg powder came from a Belgian feed producer. The milk powders were obtained from the dairy industry.

NIRM analysis. The raw materials were ground with a Retsch ZM200 grinding mill (Retsch GmbH \& Co., Haan, Germany) to obtain particles with a diameter $<2 \mathrm{~mm}$. Prior to the NIRM analysis, the samples were sieved to select the fraction of the particles with a size with a diameter $>250 \mu \mathrm{m}$. Sixty particles were then manually spread on a spectralon plate. Using the microscope pointer of an auto image microscope connected to a Fourier transform near infrared spectrometer (FT-NIR; Perkin Elmer, Waltham, MA, USA), the infrared beam was focused on each particle and their NIR-spectrum $(1100-2500 \mathrm{~nm})$ was collected. The particles were arranged to be able to track the link between the spectrum and the corresponding particle. After the NIRM analysis, each particle was individually and carefully transferred in a $200 \mu \mathrm{l}$ vial for PCR analysis and its origin (animal or vegetal) was predicted by existing discrimination models (Baeten et al. 2004).

Cleaning of the particles. After NIRM analysis, the particles detected as animal are isolated and put in a $200 \mu \mathrm{l}$ vial. A cleaning procedure is then required to remove unspecific traces of DNA stuck to the particle before the DNA extraction (see the result section). Different reagents degrading the DNA were tested alone or in combination to clean the particles: DNA Erase (MP Biomedicals, Solon, Ohio, USA), RBS (Chemical Products R. Borghgraef s.a., Brussels, Belgium), hydrogen peroxide, acetone and isopropanol. Different incubation times and/or concentrations were tested. The protocols described here are the final ones giving the best results.

Cleaning with DNA Erase. The DNA Erase is classically used in laboratories to clean and decontaminate from DNA traces small equipments (e.g. pipets) or working surfaces. The cleaning is realised by adding $100 \mu \mathrm{l}$ of DNA Erase to the particle. The vial is gently shaken during 4 min and 
briefly centrifuged in a centrifuge 2K15 (SIGMA Laborzentrifugen GmbH, Osterode, Germany) before to remove the DNA Erase. The particle is then rinsed with $100 \mu$ l of PCR-grade water (ICN Biomedicals Inc., Aurora, OH, USA) and dried in a concentrator 5301 (Eppendorf AG, Hamburg, Germany).

Cleaning with RBS. The RBS is a detergent used in our lab for the cleaning of the mill used to grind the samples. The particle is incubated in $100 \mu$ of RBS diluted 1 vol:19 vol in water for 2 min and briefly centrifuged in a centrifuge 2K15 (SIGMA Laborzentrifugen GmbH, Osterode, Germany) before to remove the RBS. The particle is then rinsed with $100 \mu \mathrm{l}$ of PCR-grade water (ICN Biomedicals Inc., Aurora, $\mathrm{OH}, \mathrm{USA}$ ) and dried in a concentrator 5301 (Eppendorf AG, Hamburg, Germany).

Cleaning with hydrogen peroxide. The particle incubates in $100 \mu \mathrm{l}$ of a solution of hydrogen peroxide at $30 \%$ during $2 \mathrm{~min}$. The vial is then briefly centrifuged in a centrifuge 2K15 (SIGMA Laborzentrifugen $\mathrm{GmbH}$, Osterode, Germany) and the hydrogen peroxide is removed. The particle is then rinsed with $100 \mu \mathrm{l}$ of PCR-grade water (ICN Biomedicals Inc., Aurora, OH, USA) and dried in a concentrator 5301 (Eppendorf AG, Hamburg, Germany).

Cleaning with acetone and isopropanol. A first cleaning is realised by adding $100 \mu \mathrm{l}$ of acetone (ICN Biomedicals Inc., Aurora, $\mathrm{OH}$, USA) to the particle. The vial is gently shaken by inverting four times and briefly centrifuged in a centrifuge 2K15 (SIGMA Laborzentrifugen GmbH, Osterode, Germany) before to remove the acetone. The cleaning process is managed so that the particle is in contact with the reagent during $2 \mathrm{~min}$. A second cleaning with $100 \mu$ l of isopropanol (Sigma Aldrich Chemie GmbH, Steinheim, Germany) is immediately performed using the same way and timing. The particle is then rinsed with $100 \mu \mathrm{l}$ of PCR-grade water (ICN Biomedicals Inc., Aurora, OH, USA) and dried in a concentrator 5301 (Eppendorf AG, Hamburg, Germany).

DNA extraction from a single particle. Several kits dedicated to DNA extraction from small amount of starting material were identified and tested: Invisorb ${ }^{\circledR}$ Spin Tissue Mini Kit and Invisorb ${ }^{\circledR}$ Spin 
Forensic Kit (Invitek GmbH, Berlin, Germany) are two kits in which a lysis step with a buffer is followed by a purification step on a spin column. Invisorb ${ }^{\circledR}$ Forensic Kit I (Invitek GmbH, Berlin, Germany) is a kit using the nanoparticles technology to recover the DNA extracted after the lysis step. Two other DNA extraction kits, PicoPure ${ }^{\mathrm{TM}}$ DNA Extraction Kit (Arcturus Bioscience, Mountain View, CA, USA) and Direct PCR ${ }^{\circledR}$ (tail) Lysis Reagent for Genotyping using Crude Lysates (Viagen Biotech Inc., Los Angeles, CA, USA), were also tested. These latter 2 kits allow to get a ready-to-use DNA extract directly after the lysis in a buffer.

The protocols presented here are the ones adapted to our specific application according to the constraints developed in the Results and discussion part of the paper from the original guidelines provided by the suppliers.

Invisorb ${ }^{\circledast}$ Spin Tissue Mini Kit is used to extract and purify DNA from small amounts $(0.5-40 \mathrm{mg})$ of animal tissue. The lysis step of the particle is performed with $400 \mu \mathrm{l}$ of Lysis Buffer $\mathrm{G}$ containing $40 \mu \mathrm{l}$ of a Proteinase K solution provided with the kit. The lysate is centrifuged at $12000 \mathrm{rpm}$ during $2 \mathrm{~min}$. Fourty $\mu \mathrm{l}$ of RNAse A (10 mg/ml) are added to the supernatant recovered and incubated at room temperature during $5 \mathrm{~min}$. After the addition of $200 \mu \mathrm{l}$ of Binding Buffer $\mathrm{T}$, the lysate is dropped on a spin column. After 1 minute, the spin column is centrifuged at $12000 \mathrm{rpm}$ for $2 \mathrm{~min}$. The spin column is then cleaned twice by the addition of $550 \mu \mathrm{l}$ of Wash Buffer followed by a centrifugation at 12000 $\mathrm{rpm}$ during $1 \mathrm{~min}$. The remaining ethanol is removed by a centrifugation at $12000 \mathrm{rpm}$ during $2 \mathrm{~min}$. Finally, the DNA is eluated by a centrifugation at $10000 \mathrm{rpm}$ during $2 \mathrm{~min}$ after an incubation during 3 $\min$ in $60 \mu$ l of Elution buffer warmed at $52^{\circ} \mathrm{C}$.

Invisorb ${ }^{\circledR}$ Spin Forensic Kit is optimised to recover small amounts of DNA from forensic samples (e.g. blood, sperm or saliva stains, stamps, cigarette butts,...). The lysis step of the particle is performed at $56{ }^{\circ} \mathrm{C}$ for 2 hours in $500 \mu \mathrm{l}$ of Lysis Buffer G containing $25 \mu$ l of a Proteinase K solution provided with 
the kit. The lysate is centrifuged at $10000 \mathrm{rpm}$ during $2 \mathrm{~min}$. After the addition of $250 \mu \mathrm{l}$ of Binding Buffer $\mathrm{T}$ to the supernatant recovered, the lysate is dropped on a spin column. After $1 \mathrm{~min}$, the spin column is centrifuged at $10000 \mathrm{rpm}$ for $1 \mathrm{~min}$. The spin column is then cleaned twice by the addition of $800 \mu \mathrm{l}$ of Wash Buffer followed by a centrifugation at $10000 \mathrm{rpm}$ during $1 \mathrm{~min}$. The remaining ethanol is removed by a centrifugation at $12000 \mathrm{rpm}$ during $3 \mathrm{~min}$. Finally, the DNA is eluated by a centrifugation at $8000 \mathrm{rpm}$ during $1 \mathrm{~min}$ after an incubation during $1 \mathrm{~min}$ in $50 \mu$ l of Elution buffer warmed at $52^{\circ} \mathrm{C}$.

Invisorb ${ }^{\circledR}$ Forensic Kit I is optimised to extract DNA from the same forensic samples as the Invisorb ${ }^{\circledR}$ Forensic Kit but can also be used with bones (the following protocol is directly derived from the one describing DNA isolation from bone or ancient bone material in the manual of the kit). The lysis step of the particle is performed at temperature between $50^{\circ} \mathrm{C}$ and $60^{\circ} \mathrm{C}$ for $15-20$ hours in $20 \mu$ l of Lysis Buffer $\mathrm{G}$ containing $4 \mu \mathrm{l}$ of Bone Lysis Enhancer solution. The lysate is centrifuged at $12000 \mathrm{rpm}$ during $2 \mathrm{~min}$ and the supernatant is recovered. Two $\mu \mathrm{l}$ of Carrier Suspension buffer made of nanoparticles are then added for an incubation at room temperature for $5 \mathrm{~min}$. The $\mathrm{mix}$ is centrifuged at $10000 \mathrm{rpm}$ for 1 second to pellet down the carrier and discard the supernatant. The nanoparticles are then cleaned twice with $20 \mu \mathrm{l}$ of Wash Buffer. After a centrifugation, the pellet of nanoparticles is dried into a vacuum dessicator at $60{ }^{\circ} \mathrm{C}$ to completely evaporate the residual ethanol. The pellet is resuspended in $20 \mu$ of Elution Buffer $D$ and incubated at $60{ }^{\circ} \mathrm{C}$ for 5 min to release the DNA from the nanoparticles. A last centrifugation allows the removing of the nanoparticles and the recovering of the DNA.

PicoPure ${ }^{T M}$ DNA Extraction Kit is developed for processing small samples of few as ten cells or several milligrams of tissue. It enables to recover high amounts of DNA ready for use in PCR assays. For optimal enzymatic activity, the lyophilised Proteinase $\mathrm{K}$ is freshly reconstituted in $155 \mu \mathrm{l}$ of 
Reconstitution Buffer. Thirty $\mu \mathrm{l}$ of the prepared buffer are added to the particle in a $200 \mu \mathrm{l}$ vial and are incubated at $65^{\circ} \mathrm{C}$ for 3 hours. Proteinase $\mathrm{K}$ is then inactivated at $95^{\circ} \mathrm{C}$ for $10 \mathrm{~min}$.

Direct $P C R^{\circledR}$ (tail) Lysis Reagent for Genotyping using Crude Lysates is dedicated to mouse tail cells lysis and gives a DNA extract ready-to-use for the PCR. The extraction buffer is freshly prepared by adding Proteinase $\mathrm{K}$ (Invitrogen, Carlsbad, CA, USA) at a concentration of $0.4 \mu \mathrm{g} / \mu \mathrm{l}$ to the Direct PCR ${ }^{\circledR}$ Lysis Reagent. Seven $\mu \mathrm{l}$ of the prepared buffer are added to the particle in a $200 \mu \mathrm{l}$ vial and are incubated at $85{ }^{\circ} \mathrm{C}$ for $45 \mathrm{~min}$. The extract with the particle is then centrifuged. Six $\mu \mathrm{l}$ of supernatant are recovered and are diluted with $24 \mu$ l of PCR-grade water (ICN Biomedicals Inc., Aurora, OH, USA).

Real-time PCR analysis. Cattle and pig primers and probes as well as real-time PCR conditions are the same as the ones presented by Fumière et al. (2006). The PCR amplifications are performed on a LightCycler 480 (Roche Diagnostics $\mathrm{GmbH}$, Mannheim, Germany) without any modification of the thermal program optimised on a GeneAmp 5700 real-time PCR device (Applied Biosystems, Foster City, CA, USA) composed of an initial decontamination step by uracyl DNA glycosylase at $50{ }^{\circ} \mathrm{C}$ for 2 min, a DNA denaturation combined to the activation of the Taq DNA polymerase performed at $95^{\circ} \mathrm{C}$ for $10 \mathrm{~min}$ and 50 cycles including a melting step at $95^{\circ} \mathrm{C}$ for $15 \mathrm{~s}$, an annealing/elongation step at 50 ${ }^{\circ} \mathrm{C}$ for $60 \mathrm{~s}$. The PCR is performed in a total volume of $35 \mu \mathrm{l}$. The reaction mix contains $5 \mu \mathrm{l}$ of DNA extract, $17.5 \mu$ l of Real Time PCR Mastermix (Diagenode, Seraing, Belgium), $1.25 \mu$ l of each primer at $3 \mu \mathrm{M}$ (Eurogentec, Seraing, Belgium), $1.25 \mu \mathrm{l}$ of double dye probe at $10 \mu \mathrm{M}$ (Eurogentec, Seraing, Belgium) and $8.75 \mu$ l of PCR-grade water (ICN Biomedicals Inc., Aurora, OH, USA).

Chicken specific primers and probe were designed using the Primer Express version 2.0.0 (Applied Biosystems, Foster City, CA, USA) from the chicken mitochondrial sequence of the Genebank database. The sequences are: for the forward primer 5'-AGC ACT AGC CTT TTA AG-3', for the reverse primer 5'-GGT TTA ATT GGG GCA T-3' and for double dye probe 5'-ACA CCC TCC CCC TTA ATG AC-3'. 
The thermal protocol is the same as for the cattle and pig probes. The PCR is performed in a total volume of $35 \mu \mathrm{l}$. The reaction mix contains $5 \mu \mathrm{l}$ of DNA extract, $17.5 \mu \mathrm{l}$ of Real Time PCR Mastermix (Diagenode, Seraing, Belgium), $1.25 \mu \mathrm{l}$ of each primer at $10 \mu \mathrm{M}$ (Eurogentec, Seraing, Belgium), 1.25 $\mu \mathrm{l}$ of double dye probe at $10 \mu \mathrm{M}$ (Eurogentec, Seraing, Belgium) and $8.75 \mu \mathrm{l}$ of PCR-grade water (ICN Biomedicals Inc., Aurora, OH, USA).

Maize and soja DNA detection were performed according to the protocols described by Kuribara et al. (2002) and Shindo et al. (2002).

\section{Results and discussion}

The first tests aiming to evaluate the feasibility to amplify the DNA from a single particle were performed using a very basic protocol: the particle was soaked in a solution of proteinase $K$ at the concentration of $1 \mu \mathrm{g} / \mu \mathrm{l}$ in the well of the PCR plate and submitted to an incubation at $60^{\circ} \mathrm{C}$ (nearby the optimum $\mathrm{t}^{\circ}$ of proteinase $\mathrm{K}$ ) during $20 \mathrm{~min}$ before the inactivation of the enzyme at $95{ }^{\circ} \mathrm{C}$ during 10 min. Only after that, the PCR mix is added to perform the PCR thermal program. The results obtained were very encouraging but it rapidly appeared that a separate DNA extraction step would be needed to work with a purified DNA template and avoid PCR troubles such as inhibition or probe degradation leading to unspecific noisy signals (Figure 1).

The origin of these unspecific signals is not totally explained but the action of nucleases degrading the probe is a credible hypothesis: particles were analysed with a mix containing all the PCR reagents with the exception of the primers so that no amplification was possible. Similar signals were observed that substantiated the presence of molecules in the mix able to hydrolyse the double dye probe as measured by the emitted fluorescence. 
As presented in the Figure 2, the pre-PCR analysis of particles is composed of a cleaning step followed by a DNA extraction. Experimentally, this last step was however developed before the cleaning tests. Indeed it was mandatory to first obtain the best PCR usable DNA before to evaluate the effect of a cleaning process on the PCR results. That is why the developments of the protocols are described in this order.

Development of a DNA extraction protocol from a single particle. Starting from the general guidelines indicated in the manuals of the kits tested, the protocols were adapted to this particular application. As our aim was to obtain enough DNA to perform more than one PCR, the modifications took mainly into account the very limited amount of starting material ( 1 animal particle between 250 and $500 \mu \mathrm{m}$ weighting around $0.03 \mathrm{mg}$ - Abbas et al., submitted in 2010) and consequently, the limited amounts of the DNA extracted by reducing the volumes of the different buffers used to extract and purify the DNA. The influence of a second parameter, the incubation lysis time, was also studied. Nevertheless, the modifications of the protocols were sometimes limited by the design of the kits: the Invisorb ${ }^{\circledR}$ Spin Tissue Mini Kit and the Invisorb ${ }^{\circledR}$ Forensic Kit involve the use of a spin column for the purification of the DNA with the requirement to use minimum volumes of buffers (e.g. for the elution, a minimum volume of $50 \mu \mathrm{l}$ is recommended by the manufacturer of the Invisorb ${ }^{\circledR}$ Spin Tissue Mini Kit).

Ten particles coming from the same three pure MBMs heat treated at $133{ }^{\circ} \mathrm{C}$ were analysed with optimised protocols. The performances obtained with the five kits are compared in Table 1.

Beside the cost of the DNA extraction per particle analysed and the time needed for extraction process, different criteria having a direct impact on the reliability of the method were examined: the risks of contamination due to manipulation, the number of available PCR replicates, the number of 
successful PCR and the number of particles successfully detected by at least one of the PCR replicates.

The numerous centrifugations to perform with the spin column after the lysis step (Invisorb ${ }^{\circledR}$ Spin Tissue Mini Kit and the Invisorb ${ }^{\oplus}$ Forensic Kit) to purify the DNA appeared to us not convenient and a possible source of contamination. Moreover, it forced us to use minimum volumes of buffers probably inducing dilutions and loss of the DNA extracts. The rates of successful PCR amplification were closely dependent of the sample and the species origin of a significant part of the particles cannot be determined. In the case of the Invisorb ${ }^{\circledR}$ Forensic Kit, additional tests were performed: a longer lysis time (e.g. overnight at $42{ }^{\circ} \mathrm{C}$ ) and the use of a Carrier RNA can be also performed in the case of extremely low amounts of DNA. Longer lysis time did not improve the successful PCR rates neither the number of particles successfully detected (data not shown). Concerning the use of a Carrier RNA, we tested a Poly(A) RNA from Roche Diagnostics as recommended by the manufacturer. Unfortunately, traces of bovine DNA were detected in the product making its use impossible for our purpose. The use of a home-made vegetal DNA coming from sojabean was also unsuccessfully tested. With the Invisorb ${ }^{\circledR}$ Forensic Kit I, the absence of spin column in the protocol helps us to adapt the volumes of the different buffers to use. Nevertheless, it was not possible to obtain any DNA extract usable for the PCR and the investigations were not carried on with that kit. With the PicoPure $^{\mathrm{TM}}$ DNA Extraction Kit (Arcturus Bioscience, Mountain View, CA, USA) and the Direct PCR ${ }^{\circledR}$ (tail) Lysis Reagent for Genotyping using Crude Lysates, manipulations are limited to an incubation of the particle in the lysis buffer to obtain a PCR ready to use DNA extract. Therefore contaminations risks are reduced. As with the Invisorb ${ }^{\circledR}$ Forensic Kit I, it was easier to modify the initial provider's protocol of these two latter kits and to adapt it to our very particular application. The successful PCR rates and the number of particles successfully detected were significantly higher than with the three Invitek kits. Nevertheless the variability of the results with respect to the type of particles (muscle or 
bone) submitted to the analysis is clearly higher with the PicoPure ${ }^{T M}$ DNA Extraction Kit than with the Direct $P C R^{\circledR}$ Lysis Reagent. Even an increase of the lysis incubation time from 3 hours to 18 hours (overnight) had a limited impact on the DNA extraction efficiency. Finally, the Direct PCR ${ }^{\circledR}$ Lysis Reagent was selected to continue the development of the method as it allowed to perform more successful PCR replicates than with the PicoPure ${ }^{\mathrm{TM}}$ DNA Extraction Kit, 5 and 2 PCR respectively, to authenticate the species origin of nearly all the particles. It must be stressed that with the DNA extraction protocol using the Direct $P C R^{\circledR}$ Lysis Reagent no more unspecific signal as described above (Figure 1) was observed.

Development of a particle cleaning protocol. The PCR analysis of a single PAPs particle is only interesting if the DNA comes from the core of this particle and not from any external source especially from possible authorised ingredients present in a mix such as a compound feed. The possible presence of DNA molecules stuck to the surface of the particle was checked by preparing 8 mixes containing ingredients from two different animal species. The DNAs of the 8 mixes extracted from a test portion of $100 \mathrm{mg}$ according to the Promega protocol described by Fumière et al. (2006) were firstly analysed by PCR. The composition of the 8 mixes and the Ct values obtained with the different PCR tests are presented in the Table 2.

Twenty MBM particles detected as from animal origin by NIRM analysis (MBM particles) and coming from 5 mixes containing one MBM and one authorised ingredient were analysed by PCR without any cleaning protocol before the extraction with the Direct PCR Lysis Reagent.

The results presented in the Table 3 show that in most of the cases a large majority of the MBM particles analysed gives a positive signal only with target corresponding to their species. These results show that the impact of the authorised ingredients can be limited when the particles are analysed according the protocol described in this paper. Nevertheless, the third mix (92\% of soja $+5 \%$ of 
chicken $\mathrm{MBM}+3 \%$ of milk powder) shows, that in some cases, the percentage of particles giving ambiguous results (positive result with more than one target) can increase and confirm that a cleaning would be useful.

The first cleaning protocol tested used a solution of bleach at $0.5 \%$ in volume as recommended by Toyoda et al. (2004) for the cleaning of sedimented bone particles. Despite modified incubation times and bleach dilutions, the DNA denaturing action of bleach was too efficient and reduced drastically the number of successful PCR. Various other degrading reagents were also tested alone or in combination as described in the material and method section: DNA Erase, RBS, hydrogen peroxide $\left(\mathrm{H}_{2} \mathrm{O}_{2}\right)$, acetone and isopropanol. Even if the NIRM analysis is able to distinguish an animal particle from a vegetal one, 20 particles of each ingredient from a mix containing $92 \%$ of Maize, $5 \%$ of a chicken MBM and $3 \%$ of cattle blood were analysed by PCR after being submitted to the different cleaning protocols. The results obtained are presented in the Table 4.

The DNA Erase cleaning protocol gives clearly the more reliable results for the analysis of MBM particles: all the chicken MBM particles remains detectable with the chicken probe whereas no trace of DNA external to the particles was detected. For the other types of particles (blood and maize), the cleaning with the DNA Erase allows high levels of detection, $100 \%$ and $90 \%$, for the blood particles and the maize particles respectively. With these two last types of particles, the frequencies of detection with the other probes are however higher. A maximum of $30 \%$ of cattle blood particles gave a signal with the chicken probe. It must be stress that MBM particles can be easily distinguished from blood and vegetal ones by a NIRM analysis. So in a global analysis process combining NIRM and PCR analysis, these types of particles would not be analysed. Compared to the other cleaning protocols, the performances obtained with the cleaning with DNA Erase were considered most promising to test it with 3 other mixes. The results of the PCR analysis of 20 particles of MBM and of the vegetal ingredient are presented in the Table 5. 


\begin{abstract}
With the MBM particles, the DNA Erase cleaning protocol allows an important decreasing of the simultaneous detection with the other animal probes. A notable exception must nevertheless be pointed out in the case of the mix containing blood powder. Seventy-five percent of the chicken MBM particles still give a positive detection with the pig probe. This result must however be attenuated by the figures presented in the Table 6. Looking at the Ct values obtained with chicken MBM particles analysed without and with the DNA Erase cleaning protocol, it clearly appears that the signals obtained with the chicken probe are significantly earlier than with the cattle probe. These results indicate that, considering similar PCR efficiencies with both probes, the number of targets coming from the core of the particle is higher than the number of targets coming from the environment of the particle. This data could be considered in itself as a first evidence of the origin of the MBM particle. Moreover, the cleaning protocol does not have the same influence on both signals: whereas the signals with the chicken probe (the probe for the species the MBM particle comes from) is slightly affected (no change or a delay of less than 2 cycles), the signals obtained with the other probes are strongly delayed (+/- 6 cycles) or completely eliminated (second mix tested in the Table 6).
\end{abstract}




\section{Conclusion}

The full application of the European legislation on the animal by-products requires reliable specific methods. Up to now, PCR is the only method able to detect the presence of animal ingredients up to the species level. Unfortunately, the impact of the PCR is limited by the use of authorised animal ingredients that are also sources of animal DNA and can interfere with the results from a legal point of view. In this paper, we demonstrate that the combination of NIRM with real-time PCR is feasible and could be integrated in a global analytical strategy as the one proposed by Fumière et al. (2009) to determine if the presence of animal constituents in feed is conform or not to the European legislation. Using a special buffer, the Direct $\mathrm{PCR}^{\circledR}$ Lysis Reagent, a rapid extraction protocol allowing the analysis of the DNA coming from a single PAPs particle with up to five different PCR targets has been developed. A protocol for the cleaning of the particles was also developed to eliminate possible DNA molecules stuck to the MBM particles surface. The protocol using the DNA Erase is the most efficient but its efficiency remains largely dependent on the sample and on the particle tested. No universal conditions could be found to eliminate totally the presence of DNA coming from authorised ingredients keeping in the same time enough PCR usable DNA from the core of the MBM particles. Nevertheless, due to their costs, the use of authorised ingredients such as egg and milk powder in feed is limited. The results obtained with real world samples containing limited amounts $(<5 \%)$ of authorised ingredients are quite encouraging and allow to authenticate the origin of a majority of the particles. Moreover when a signal is observed with more than one probe, the $\mathrm{Ct}$ values obtained reflecting the copy numbers of each species target can be used to determine the species origin of the MBM particle with a high level of confidence.

When possible, the results of previous analyses (presence of PAPs particles by classical microscopy, presence of animal species in the sample by PCR and NIRM) could even be used to focus the particle PCR analysis on a limited number of species and to use rationally the available PCR replicates for a 
1

2

4

5

6

7

8

9

10

11

12

13

14

15

16

17

18

19

20

21

reliable species authentication. Nevertheless, its use for routine analysis would be very tedious. The limitation of the method is essentially the number of particles that are manually analysed by NIRM and isolated previously to the analysis of their DNA. The overall process will be assessed soon with more complex samples.

It must be stressed that the combination of the real-time PCR could be also done with the classical microscopy following a similar protocol. Here again the analysis of a representative amount of particles is a critical point. An attractive solution to automate the identification of the suspicious particles and their isolation for the subsequent PCR analysis could be the use of a microscope coupled with a laser microdissection and pressure catapulting system. 


\section{References}

Aarts HJM, Bouw EM, Buntjer JB, Lenstra JA, van Raamsdonk LWD. 2006. Detection of bovine meat and bone meal in animal feed at level of 0.1\%. Journal of AOAC International 89(6):1443-1446.

Abbas O, Fernández Pierna JA, Boix A, von Holst C, Dardenne P, Baeten V. Key parameters for the development of a NIR Microscopic method for the quantification of processed by-products of animal origin in compound feedingstuffs. Analytical and Bioanalytical Chemistry submitted.

Bellorini S, Strathmann S, Baeten V, Fumière $\mathrm{O}$, Berben $\mathrm{G}$, Tirendi $\mathrm{S}$, von Holst $\mathrm{C}$. 2005. Discriminating animal fats and their origins: assessing the potentials of Fourier Transform infrared microscopy, gas chromatography, immunoassay and polymerase chain reaction techniques. Analytical and Bioanalytical Chemistry 382:1073-1083.

Baeten V, von Holst C, Fissiaux I, Michotte Renier A, Murray I, Dardenne P. 2004. Strategies and methods to detect and quantify mammalian tissues in feedingstuffs. Brussels: European Commission. The near infrared microscopic (NIRM) method: combination of the advantages of optical microscopy and near infrared spectroscopy (WP5-NIRM); p. 1-14. ISBN 92-894-7356-8.

Baeten V, von Holst C, Garrido A, Vancutsem J, Michotte Renier A, Dardenne P. 2005. Detection of banned meat and bone meal in feedingstuffs by near-infrared analysis of the sediment fraction. Analytical and Bioanalytical Chemistry 382:149-157.

Cawthraw S, Saunders GC, Martin TC, Sawyer J, Windl O, Reaney SD. 2009. Real-Time PCR Detection and Identification of prohibited Mammalian and Avian Material in Animal Feeds. Journal of Food Protection 72(5):1055-1062.

De La Haba MJ, Fernández Pierna JA, Fumière O, Garrido-Varo A, Guerrero JE, Pérez-Marín DC, Dardenne P, Baeten V. 2007. Discrimination of fish bones from other animal bones in the sedimented 
fraction of compound feeds by near infrared microscopy (NIRM). Journal of Near Infrared Spectroscopy 15: 81-88.

Fumière $\mathrm{O}$, Dubois $\mathrm{M}$, Baeten $\mathrm{V}$, von Holst $\mathrm{C}$, Berben G. 2006. Effective PCR detection of animal species in highly processed animal byproducts and compound feeds. Analytical and Bioanalytical Chemistry 385:1045-1054.

Fumière $O$, Veys $P$, Boix $A$, von Holst $C$, Baeten V, Berben G. 2009. Methods of detection, species identification and quantification of processed animal proteins in feedingstuffs. Biotechnologie Agronomie Société Environnement 13(S):59-70.

Kuribara H, Shindo Y, Matsuoka T, Takubo K, Futo S, Aoki N, Hirao T, Akiyama H, Goda Y, Toyada M, Hino A. 2002. Novel reference molecules for quantitation of genetically modified maize and soybean. Journal of AOAC International 85(5):1077-1089.

Prado M, Berben G, Fumière O, van Duijn G, Mensinga-Kruize J, Reaney S, Boix A, von Holst C. 2007. Detection of ruminant meat and bone meals in animal feed by real time Polymerase Chain Reaction: result of an interlaboratory study. Journal of Agricultural and Food Chemistry 55:7495-7501.

Piraux F, Dardenne P. 2000. Microscopie-NIR appliqué aux aliments du bétail. Biotechnologie Agronomie Société Environnement 4(4):226-232.

SAFEED-PAP. Detection of presence of species-specific processed animal proteins in animal feed.[cited 2010 Feb 25]. Available from: http://safeedpap.feedsafety.org

Shindo Y, Kuribara H, Matsuoka T, Futo S, Sawada C, Shono J, Akiyama H, Goda Y, Toyoda M, Hino A. 2002. Validation of real time PCR analyses for line-specific quantitation of genetically modified maize and soybean using new references molecules. Journal of AOAC International 85(5):1119-1126.

Stratfeed. Strategies and methods to detect and quantify mammalian tissues in feedingstuffs. [cited 2010 Feb 25]. Available from: http://stratfeed.cra.wallonie.be 
Toyoda A, Nakajo M, Kawachi H, Matsui T, Yano A. 2004. PCR Detection of Bovine Mitochondrial DNA Derived from Meat and Bone Meal in Feed. Journal of Food Protection 67(12):2829-2832.

von Holst C, Baeten V, Boix A, Slowikowski B, Fernández Pierna JA, Tirendi S, Dardenne P. 2008. Transferability study of a near-infrared microscopic method for the detection of banned and bone meal in feedingstuffs. Analytical and Bioanalytical Chemistry 392:313-317. 


\section{Acknowledgements}

The research presented in this paper was supported by the Belgian Federal Public Service for Health, Food Chain Safety and Environment (Contract Nr S-6168) and the European Community within the framework of the SAFEED-PAP project (FOOD-CT-2006-036221) of the $6^{\text {th }}$ EC Framework Program. 


\section{List of captions}

Table 1. Comparative performances of Invisorb ${ }^{\circledR}$ Spin Tissue Mini Kit, Invisorb ${ }^{\circledR}$ Forensic Kit, Invisorb ${ }^{\circledR}$ Forensic Kit I, PicoPure ${ }^{\mathrm{TM}}$ DNA Extraction Kit and Direct $\mathrm{PCR}^{\circledR}$ (tail) Lysis Reagent for Genotyping using Crude Lysates.

Table 2. PCR analysis of DNAs from 8 mixes containing 2 animal ingredients: Ct values ( $n=2$ extracts) obtained for the detection of chicken, cattle, pig, sojabean and maize DNA.

Table 3. PCR analysis of 20 MBM particles detected as from animal origin after NIRM analysis. Percentages of detection with the Chicken probe, the Cattle probe and the Pig probe.

Table 4. PCR analysis of 20 particles of each ingredient from a mix containing $92 \%$ of Maize, $5 \%$ of a chicken MBM and $3 \%$ of cattle blood. Percentages of detection with the Chicken probe, the Cattle probe and the Maize probe.

Table 5. PCR analysis of 20 particles of MBM and of vegetal ingredient from three mixes. Percentages of detection with the Chicken probe, the Cattle probe, the Pig probe, the Maize probe and the Sojabean probe.

Table 6. PCR analysis of MBM and blood particles of 2 mixes. Comparison of mean Ct values in number of cycles with the Chicken probe, the Cattle probe and the Pig probe with and without a DNA Erase cleaning protocol of the particles.

Figure 1. Real time PCR signals obtained with a pig MBM particle using the cattle and pig probes. The grey line is a normal amplification obtained with the pig probe. The black line is an unspecific signal obtained with the cattle probe. 
Figure 2. Overall analytical process of PAPs particles combining NIRM and Real Time PCR analysis. The present paper is focussing on steps \# 3, 4, 5 and 6 . 


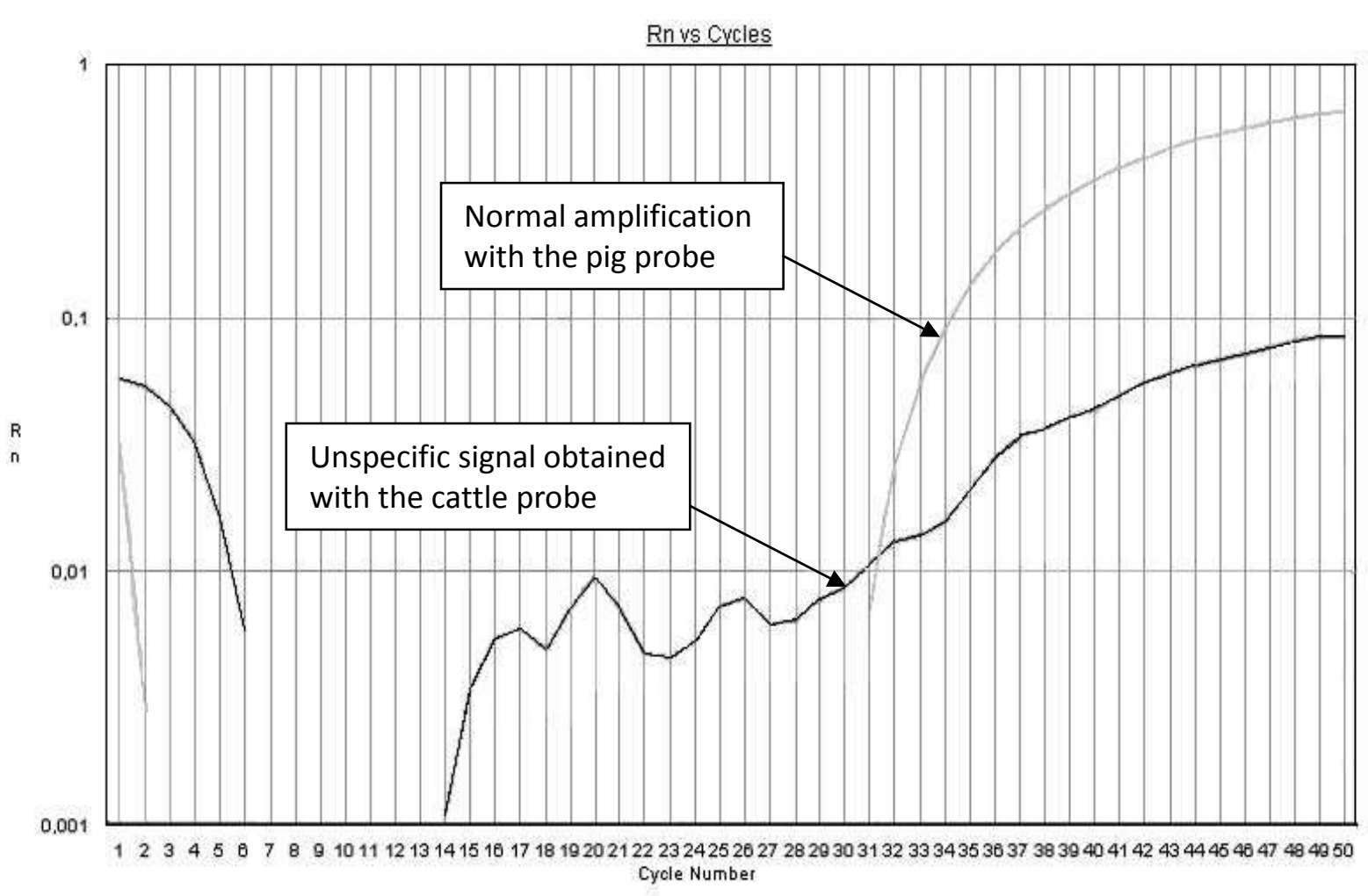

Figure 1. Real time PCR signals obtained with a pig MBM particle using the cattle and pig probes. 


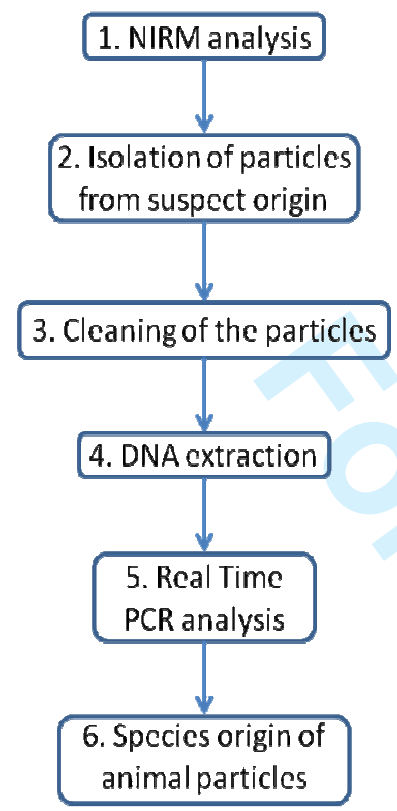

Figure 2. Overall analytical process of PAPs particles combining NIRM and Real Time PCR analysis. The present paper is focussing on steps \# 3, 4, 5 and 6.

Or

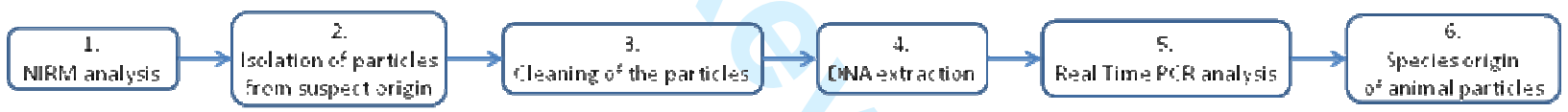

Figure 2. Overall analytical process of PAPs particles combining NIRM and Real Time PCR analysis. The present paper is focussing on steps \# 3, 4, 5 and 6. 
Table 1. Comparative performances of Invisorb ${ }^{\circledR}$ Spin Tissue Mini Kit, Invisorb ${ }^{\circledR}$ Forensic Kit, Invisorb ${ }^{\circledR}$ Forensic Kit I, PicoPure ${ }^{\mathrm{TM}}$ DNA Extraction Kit and Direct PCR ${ }^{\circledast}$ (tail) Lysis Reagent for Genotyping using Crude Lysates.

\begin{tabular}{|c|c|c|c|c|c|}
\hline & $\begin{array}{l}\text { Invisorb }{ }^{\circledR} \text { Spin } \\
\text { Tissue Mini Kit }\end{array}$ & $\begin{array}{c}\text { Invisorb }^{\circledR} \text { Forensic } \\
\text { Kit }\end{array}$ & $\begin{array}{c}\text { Invisorb }^{\circledR} \text { Forensic } \\
\text { Kit I }\end{array}$ & $\begin{array}{c}\text { PicoPure }^{\mathrm{TM}} \text { DNA } \\
\text { Extraction kit }\end{array}$ & $\begin{array}{l}\text { Direct PCR }{ }^{\circledR} \\
\text { Lysis Reagent }\end{array}$ \\
\hline Cost /DNA extraction & $2.58 €$ & $3.17 €$ & $0.80 €$ & $2.56 €$ & $0.01 €$ \\
\hline Extraction time & 1.5 hour & 2.5 hours & $15-20$ hours & 3 hours & 45 minutes \\
\hline Contamination risk & High & High & Medium & Low & Low \\
\hline Number of PCR & 5 & 4 & 2 & 2 & 5 \\
\hline Successful PCR rates & $10-65 \%$ & $70-85 \%$ & $0 \%$ & $75-100 \%$ & $96-100 \%$ \\
\hline Particles successfully detected & $10-70 \%$ & $70-90 \%$ & $0 \%$ & $80-100 \%$ & $100 \%$ \\
\hline
\end{tabular}

Table 2. PCR analysis of DNAs from 8 mixes containing 2 animal ingredients: Ct values ( $n=2$ extracts) obtained for the detection of chicken, cattle, pig, sojabean and maize DNA.

\begin{tabular}{|c|c|c|c|c|c|}
\hline Mixes (\% in weight of ingredients) & Ct Chicken & Ct Cattle & Ct pig & Ct Sojabean & Ct Maize \\
\hline Sojabean (92 \%) + Chicken MBM \#1 (5 \%) + Milk powder \#1 (3\%) & 25.90 & \multirow{8}{*}{$\begin{array}{c}38.47 \\
32.09 \\
32.49 \\
25.41 \\
\mathrm{NT}^{\mathrm{a}} \\
34.79 \\
\mathrm{NT}^{\mathrm{a}} 25.98\end{array}$} & & \multirow{8}{*}{$\begin{array}{c}28.90 \\
28.05 \\
28.50 \\
N T^{\mathrm{a}} \mathrm{NT}^{\mathrm{a}} \mathrm{NT}^{\mathrm{a}} \\
\mathrm{NT}^{\mathrm{a}} \mathrm{NT}^{\mathrm{a}}\end{array}$} & \multirow{3}{*}{$\begin{array}{l}\mathrm{NT}^{\mathrm{a}} \mathrm{NT}^{\mathrm{a}} \\
\mathrm{NT}^{\mathrm{a}} 29.16\end{array}$} \\
\hline Sojabean (92 \%) + Chicken MBM \#1 (5 \%) + Milk powder \#2 (3 \%) & 24.90 & & $N T^{a} N T^{a}$ & & \\
\hline Sojabean (92 \%) + Chicken MBM \#2 (5 \%) + Milk powder \#2 (3 \%) & 27.52 & & $N T^{\mathrm{a}} N T^{\mathrm{a}}$ & & \\
\hline Maize $(92 \%)+$ Cattle MBM (5 \%) + Egg powder (3\%) & 29.74 & & 32.56 & & 28.81 \\
\hline Maize $(92 \%)+$ Pig MBM (5 \%) + Egg powder (3 \%) & 29.73 & & $N T^{a}$ & & 30.37 \\
\hline Maize (92 \%) + Chicken MBM \#1 (5\%) + Cattle blood (3\%) & 23.09 & & 25.79 & & 29.08 \\
\hline Maize (92 \%) + Chicken MBM \#3 (5 \%) + Pig blood (3 \%) & 23.03 & & $N T^{a}$ & & $N T^{\mathrm{a}}$ \\
\hline Chicken MBM \#1 (50 \%) + Milk powder \#2 (50\%) & 19.08 & & & & \\
\hline
\end{tabular}

Table 3. PCR analysis of 20 MBM particles detected as from animal origin after NIRM analysis. Percentages of detection with the Chicken probe, the Cattle probe and the Pig probe.

\begin{tabular}{|c|c|c|c|}
\hline Mixes (\% in weight of ingredients) & Chicken & Cattle & Pig \\
\hline Sojabean $(92 \%)+$ Chicken MBM \#1 (5 \%) + Milk powder \#1 (3\%) & $100 \%$ & $0 \%$ & $N T^{a}$ \\
\hline Sojabean $(92 \%)+$ Chicken MBM \#1 (5 \%) + Milk powder \#2 (3 \%) & $100 \%$ & $5 \%$ & $N T^{a}$ \\
\hline Sojabean (92 \%) + Chicken MBM \#2 (5 \%) + Milk powder \#2 (3\%) & $95 \%$ & $20 \%$ & $N T^{a}$ \\
\hline Maize $(92 \%)+$ Cattle MBM (5 \%) + Egg powder (3 \%) & $0 \%$ & $100 \%$ & $\mathrm{NT}^{\mathrm{a}}$ \\
\hline Maize (92 \%) + Pig MBM (5 \%) + Egg powder (3 \%) & $5 \%$ & $N T^{\mathrm{a}}$ & $95 \%$ \\
\hline Maize $(92 \%)+$ Chicken MBM \#1 (5\%) + Cattle blood (3\%) & $100 \%$ & $40 \%$ & $90 \%$ \\
\hline Maize (92 \%) + Chicken MBM \#3 (5 \%) + Pig blood (3 \%) & $100 \%$ & $\mathrm{NT}^{\mathrm{a}}$ & $100 \%$ \\
\hline Chicken MBM \#1 (50\%) + Milk powder \#2 (50\%) & $100 \%$ & $55 \%$ & $N T^{a}$ \\
\hline
\end{tabular}

${ }^{\mathrm{a}} \mathrm{NT}$ : not tested

Table 4. PCR analysis of 20 particles of each ingredient from a mix containing $92 \%$ of Maize, $5 \%$ of a chicken MBM and $3 \%$ of cattle blood. Percentages of detection with the Chicken probe, the Cattle probe and the Maize probe.

\begin{tabular}{|c|c|c|c|c|c|c|c|c|c|c|c|c|c|c|c|}
\hline \multirow[t]{2}{*}{$\begin{array}{l}\text { Type of } \\
\text { particle }\end{array}$} & \multicolumn{3}{|c|}{ Without cleaning protocol } & \multicolumn{3}{|c|}{ With RBS cleaning protocol } & \multicolumn{3}{|c|}{$\begin{array}{l}\text { With DNA Erase cleaning } \\
\text { protocol }\end{array}$} & \multicolumn{3}{|c|}{ With $\mathrm{H}_{2} \mathrm{O}_{2}$ cleaning protocol } & \multicolumn{3}{|c|}{$\begin{array}{l}\text { With acetone-isopropanol } \\
\text { cleaning protocol }\end{array}$} \\
\hline & Chicken & Cattle & Maize & Chicken & Cattle & Maize & Chicken & Cattle & Maize & Chicken & Cattle & Maize & Chicken & Cattle & Maize \\
\hline Chicken MBM & $100 \%$ & $60 \%$ & $90 \%$ & $100 \%$ & $5 \%$ & $5 \%$ & $100 \%$ & $0 \%$ & $0 \%$ & $100 \%$ & $5 \%$ & $40 \%$ & $100 \%$ & $40 \%$ & $60 \%$ \\
\hline Cattle blood & $100 \%$ & $100 \%$ & $100 \%$ & $90 \%$ & $100 \%$ & $45 \%$ & $30 \%$ & $100 \%$ & $15 \%$ & $35 \%$ & $95 \%$ & $60 \%$ & $100 \%$ & $100 \%$ & $95 \%$ \\
\hline Maize & $100 \%$ & $45 \%$ & $95 \%$ & $15 \%$ & $0 \%$ & $95 \%$ & $5 \%$ & $10 \%$ & $90 \%$ & $100 \%$ & $20 \%$ & $95 \%$ & $95 \%$ & $10 \%$ & $90 \%$ \\
\hline
\end{tabular}

Table 5. PCR analysis of 20 particles of MBM and of vegetal ingredient from three mixes. Percentages of detection with the Chicken probe, the Cattle probe, the Pig probe, the Maize probe and the Sojabean probe. 


\begin{tabular}{|c|c|c|c|c|c|c|c|c|c|c|c|}
\hline \multirow[b]{2}{*}{ Mixes (\% in weight of ingredients) } & \multirow[b]{2}{*}{$\begin{array}{l}\text { Particles } \\
\text { analysed }\end{array}$} & \multicolumn{5}{|c|}{ Without cleaning protocol } & \multicolumn{5}{|c|}{ With DNA Erase cleaning protocol } \\
\hline & & Chicken & Cattle & Pig & Maize & Sojabean & Chicken & Cattle & Pig & Maize & Sojabean \\
\hline Chicken MBM \#1 (50\%) + Milk powder \#2 (50\%) & Chicken MBM & $100 \%$ & $70 \%$ & $\mathrm{NT}^{\mathrm{a}}$ & $N T^{a}$ & $N T^{a}$ & $95 \%$ & $5 \%$ & $\mathrm{NT}^{\mathrm{a}}$ & $N T^{a}$ & $N T^{\mathrm{a}}$ \\
\hline \multirow{2}{*}{$\begin{array}{l}\text { Soja }(92 \%)+\text { Chicken MBM \#1 (5 \%) } \\
\text { + Milk powder \#2 }(3 \%)\end{array}$} & Chicken MBM & $95 \%$ & $20 \%$ & $\mathrm{NT}^{\mathrm{a}}$ & $N T^{a}$ & $85 \%$ & $100 \%$ & $0 \%$ & $\mathrm{NT}^{\mathrm{a}}$ & $N T^{a}$ & $0 \%$ \\
\hline & Sojabean & $80 \%$ & $5 \%$ & $N T^{a}$ & $N T^{a}$ & $95 \%$ & $5 \%$ & $0 \%$ & $N T^{\mathrm{a}}$ & $N T^{a}$ & $95 \%$ \\
\hline \multirow{2}{*}{$\begin{array}{l}\text { Maize }(92 \%)+\text { Chicken MBM \#3 (5\%) } \\
\text { + Pig blood (3\%) }\end{array}$} & Chicken MBM & $100 \%$ & $\mathrm{NT}^{\mathrm{a}}$ & $100 \%$ & $95 \%$ & $N T^{a}$ & $100 \%$ & $\mathrm{NT}^{\mathrm{a}}$ & $75 \%$ & $5 \%$ & $N T^{\mathrm{a}}$ \\
\hline & Maize & $100 \%$ & $N T^{\mathrm{a}}$ & $100 \%$ & $95 \%$ & $N T^{a}$ & $10 \%$ & $\mathrm{NT}^{\mathrm{a}}$ & $15 \%$ & $85 \%$ & $N T^{\mathrm{a}}$ \\
\hline
\end{tabular}

Table 6. PCR analysis of MBM and blood particles of 2 mixes. Comparison of mean $\mathrm{Ct}$ values in number of cycles with the Chicken probe, the Cattle probe and the Pig probe with and without a DNA Erase cleaning protocol of the particles.

\begin{tabular}{|c|c|c|c|c|c|c|c|}
\hline & & \multicolumn{3}{|c|}{ Without cleaning protocol } & \multicolumn{3}{|c|}{ With DNA Erase cleaning protocol } \\
\hline Mixes (\% in weight of ingredients) & Particles analysed & Chicken & Cattle & Pig & Chicken & Cattle & Pig \\
\hline $\begin{array}{l}\text { Maize }(92 \%)+\text { Chicken MBM \#3 }(5 \%)+\text { Pig } \\
\text { blood }(3 \%)\end{array}$ & Chicken MBM & 21.64 & $\mathrm{NT}^{\mathrm{a}}$ & 31.90 & 21.52 & $N T^{a}$ & 37.55 \\
\hline \multirow{2}{*}{$\begin{array}{l}\text { Maize }(92 \%)+\text { Chicken MBM \#1 (5\%) + Cattle } \\
\text { blood }(3 \%)\end{array}$} & Chicken MBM & 23.27 & 39.00 & $N T^{a}$ & 25.10 & $N D^{b}$ & $N T^{a}$ \\
\hline & Cattle blood & 29.54 & 29.47 & $\mathrm{NT}^{\mathrm{a}}$ & 36.74 & 29.74 & $N T^{\mathrm{a}}$ \\
\hline
\end{tabular}

${ }^{\mathrm{a}} \mathrm{NT}$ : not tested

${ }^{\mathrm{b}} \mathrm{ND}:$ not detected 